\title{
'Follow me, and I will make you fishers of men': The moral and political scales of migration in the Central Mediterranean
}

\author{
Naor Ben-Yehoyada \\ (MA, Tel Aviv University, 2005; PhD, Harvard University, 2011); Research Fellow in Social \\ Anthropology, Gonville and Caius College, Associated Researcher at the Consiglio Narionale delle \\ Ricerche-Iamc, Sicily. His interests include maritime and political anthropology of transnational \\ region formation in the Mediterranean, specifically in Israel-Palestine and between Sicily and \\ Tunisia.
}

\author{
Gonville and Caius College \\ Trinity Street \\ Cambridge CB2 1TA \\ United Kingdom \\ nhb27@,cam.ac.uk
}

\begin{abstract}
This paper offers recent dynamics of unauthorized migration and interception in the central Mediterranean as an example of historical anthropology of transnational region formation. It exemplifies how we can rescale classical themes in Mediterraneanist anthropology - hospitality, in this case - to illuminate transnational processes. I argue that anthropologists actually share with Human Rights advocates and European officials these ways of thinking about the scales of the moral and the political dimensions of migration, and I offer an alternative understanding of the scales of action, responsibility, and sovereignty as well as clue about how regions come to life.
\end{abstract}


In the summer of 2009, the Bishop of the Sicilian town of Mazara del Vallo celebrated Holy Mass in an unprecedented way - from an altar mounted on the upper deck of an Italian Coastguard ship. The ship was anchored, together with the fishing boat tied up alongside it, off the leeward shore of the Italian island of Pantelleria, almost equidistant between the Sicilian and Tunisian shores. ${ }^{1}$

The position of this seaborne mass - afloat at the center of the Mediterranean - served the ritual staging of a macrocosmic transformation. Both during the mass and afterwards, the Bishop conjured up the space of Holy Communion as 'the Mediterranean, this great Lake of Galilee.' By casting the twenty-first century Mediterranean as the Gospel's Lake of Galilee, the Bishop expanded the ritual act of communion and recast all its elements: the coastguard ship as St. Peter's boat and the participating Sicilian fishers as the Apostles. When, during the seaborne mass, the bishop iterated Christ's words to Simon and Andrew: 'Follow me, and I will make you fishers of men,' he cast the unauthorized migrants in danger of drowning as souls in need of salvation and, by implication, the Italian State and the European Union as Herod and the Pharisees. The ritual casting served the Bishop in justifying and applauding the fishers of his diocese's fleet for responding to distress calls made by boats carrying clandestine migrants en route to Italian shores. The fishers' act exemplified Mediterranean hospitality.

Mazara del Vallo is the closest Sicilian town to the Tunisian shore. The town, which nowadays counts about fifty thousand inhabitants, has seen millennia of connections to the other side of the Sea, and it has played a central role in cross-Mediterranean affairs during the last sixty years: fish wars, labor migration, drugs and arms trafficking, and transnational infrastructure projects. Mazara's role in both recent and remote histories made the town one of the Sicilian hubs of Mediterraneanism. Many economic, political, and cultural projects in town carry the word 'Mediterranean.' And they have all sought to secure the town's role in the region and help its 
economy. The bishop initiated some of these projects and gave his blessing to many others. The seaborne Holy Mass extended the same strategy to intervene in the new transnational dynamics of unauthorized migration and interception, which were engulfing Mazara and its fleet.

The Mediterranean is back. It has reemerged in the international news cycle as the sea that migrants try to cross towards European shores - where many of them die. For Europeans, these events have turned the Mediterranean into a mirror that reflects their dilemmas about the tensions between the bounds of their political union and boundless humanity.

Anthropologists do not know what to do with the Mediterranean. On the one hand, its shores served as ethnographic breeding grounds for classic themes like hospitality, patronage, and networks. On the other hand, the most ambitious treatises about the elementary forms of kinship stayed away from the Mediterranean (to mention two examples, Lévi-Strauss 1969; Sahlins 2013). Instead, they followed neater examples of what Germaine Tillion called 'republics of brothers-inlaw' (1983). In regionalist scholarship, anthropologists had once searched for the cultural unity of the Mediterranean, but then dismissed this search as a form of orientalism (Herzfeld 2005). This conclusion eliminated the sea as a candidate for understanding the processes that form transnational regions.

This paper offers recent events in the central Mediterranean as an example of historical anthropology of transnational region formation. I propose viewing transnational regions as everchanging constellations, which form and dissipate through the interaction between cross-boundary practices and official region-making projects. And I show how we can examine these dynamics from the moving vessels that lace these constellations together and stage their social relations in full view. This double attention to seaborne vessels and historical process shows how regions become 
palpable. By returning to the Mediterranean, we may acquire new lenses for examining transnationalism the world over.

A return to the Mediterranean enables us to reframe classical themes from Mediterraneanist anthropology to illuminate processes of region formation. The theme considered here is hospitality, or, as Pitt-Rivers put it, 'the problem of how to deal with strangers' $(1977,94)$. The process is the dynamics of unauthorized migration and interception in the central Mediterranean, where a struggle emerged over the meaning of the Law of the Sea and the universal hospitality it implies. The essay contains three parts. I first revisit the role of temporal and spatial scales in classical accounts of hospitality. I then turn to the transnational working of hospitality. Here I examine how the dynamics of unauthorized migration, interception policies, and rescue at sea aligned the ways that Human Rights advocates and European officials addressed the moral and the political dimensions of the ongoing situation. I explain how the delineation of the moral and the political aspects of migration policies emerged from the dynamics of maritime migration and interdiction, and how the scales of responsibility, jurisdiction, and sovereignty depended on the 'scalar elasticity of hospitality itself, which is always of a place but inherently transportable' (Shryock 2012, S23). Third, I analyze the Sacrament of the Eucharist that the Mazara Bishop performed during his pastoral visit. I focus on the alternative view of transnational hospitality that the ceremony formulated; on the jurisdictional tensions that the ceremony reveals; and on the liturgical change from the pastoral visit to the Pope's subsequent intervention in 2013.

In the conclusion, I argue that anthropologists actually share with Human Rights advocates and European officials these ways of thinking about the scales of the moral and the political. Like advocates and officials, anthropologists set their scale of reference at the paramount scale of a global 'shared humanity' and pan-human fraternal parity and sameness; even if some of them treat 
this scale politically (e.g., Ticktin 2011) and others view it morally (Fassin 2012). I then build on the transnational dynamics of hospitality to offer an alternative understanding of the scales of action, responsibility, and sovereignty, as well as a better grasp of how regions come to life. Here, the moral and the political appear not as a duo of nested scales, but rather as entwined aspects of action across scales, which includes the struggle between competing scaling projects. These projects not only affect the relationship between the moral and the political. They also shape the formation and transformation of those scale of action which lie between the local and the global - transnational regions like the Mediterranean - how palpable they seem and what they come to stand for.

\section{Hospitality writ large}

Hospitality ritualizes the encounter of host and guest, intended to replace potential conflict with unknown strangers by a turn-taking game of honor (Candea and Da Col 2012). In a way, hospitality ritually prohibits equality between the sides to the interaction, in the name of their potential equality and reciprocity on a wider scale. As a result, hospitality turns equality and reciprocity into what host and guest negotiate (Shryock 2012). When they do so, they invoke the moral and political dimensions of action on different scales of time and space. This negotiation of scales stood at the heart of classical treatments of hospitality. The following two examples show this; the first temporally, the second spatially.

In 'the law of hospitality,' Pitt-Rivers describes the customs regarding begging in Andalusia (1977, 102-3). When beggars ask for alms, they invoke God. Once gratified, they reply: 'May God repay you' [which means] 'Because I cannot."' The 'promise of repayment' and the 'axis of reciprocity' move from the mortal plane to Heaven. If the potential donor refuses to give alms, they use a phrase that 'carries the same import: [...] "Excuse me, in God's name, Brother." Here, refusal to count on repayment in Heaven asserts equality on earth with the beggar, whom they call 'brother.' 
Another phrase, "'May God protect you, Brother," [carries the] same implication: "Because I am not going to."

This example shows how hospitality frames moments of inequality by scaling them temporally upwards to an eschatological time when equality can be reestablished: as brothers on earth, or as souls in heaven. The second example - Michael Herzfeld's account of how Cretans treat strangers in coffeehouses - reveals its spatial side $(1987,78)$. During his fieldwork in Glendi, he visited a nearby village that was notoriously inhospitable. When he reported back that he had not been warmly received in the coffeehouse, Herzfeld's audience concluded: 'Mikhalis has learned the Glendiot customs!' The other villagers' bad hospitality proved Glendiots as morally superior, and in declaring that, they included Herzfeld as their own. This incorporation shows how the meaning of both the stranger and the hospitality act depends on the relation between speaker and audience. As a result, acts of hospitality reaffirm what Herzfeld calls 'a homology between several levels of collective identity... What goes for the family home also goes, at least by metaphorical extension, for the national territory' $(1987,76)$.

These two examples show how acts of hospitality dramatize social relations by framing interaction between host and guest within temporal and spatial scales of inclusion and exclusion. The participants themselves project these scales onto the event. Demands, acts, and accounts of hospitality slice the world into the domestic realm and the outside with its strangers and the obligation their arrival entails (Candea 2012). The moral here appears as the standard of shared sociality and potential equality between the host and the guest. The political appears as the host's mastery over the bounded space and its community. By welcoming strangers into their realm for a limited period, hosts assert their sovereignty over that space. Temporary inclusion establishes categorical exclusion. This is perhaps what distinguishes anthropologies of hospitality from those of 
the gift (Candea and Da Col 2012, S1-2). While both focus on turn-taking acts, work on hospitality includes a notion of the mastery of spatial realm. In acts of hospitality, hosts try to prove their honor by showing the integrity of their domestic spaces and their mastery over 'the threshold of welcome or trespass' (Shryock 2012, S24).

Anthropologists have examined these dynamics in villages, tribal tents, and the like. Yet the same slicing of the world into the moral and the political has operated at a much vaster scale - at sea. In the last decade or so, the Mediterranean has increasingly staged this threshold in European migration politics. By veering our attention towards the sea, we get a dynamic view of what the political and the moral aspects of action come to stand for on a transnational scale, when Europeans grapple with 'how to deal with strangers.'

The sea contains all the necessary ingredients for this amplified dramatization. First, it contains a moveable border. Second, the sea - because of its material properties - has not traditionally followed the rules of landed territoriality or sovereignty (Steinberg 2001; Benton 2010). It is also a dangerous place, where people perish. These traits made European political thinkers since Immanuel Kant pose the problem of universal hospitality through 'the Law of the Sea' - the moral obligation to assist strangers in danger of drowning regardless of who they are (Benhabib 2004; Kant 2006). In modern European political imagination, seas have featured in a double role. Their spaces represented the ultimate realm of freedom, of 'natural law' of 'hospitality which is of the highest sanctity' (Grotius 1916, 8). The emblematic inhabitants of these spaces - especially earlymodern Barbary pirates in the Mediterranean and 'camel-raiding Bedouin' - played in this political imagination the threatening 'political fringe dwellers' (Shryock 2008, 412). Unruly space and its inhospitable inhabitants have together embodied the moral horizon of a double-threaded expansion of law and rule: the uneven basing of international law on 'the law of the sea' and the equally 
uneven spread of the search for imperial sovereignty and inter-imperial relations. ${ }^{2}$ Once the sea signified the realm beyond the pale of government, the moral imperative appeared as a universal human standard towards which specific national and imperial political projects should aspire. The proclamation of this universal hospitality set a temporal as well as a spatial horizon. It posed a moral alternative outside realms of territorial sovereignty by displacing this 'natural law' in space - to the seas (and deserts) - and in time to a future cosmopolitan peace (Shryock 2009). This view of universal humanity makes a moral standard the aim of the political action of legalization. The alternative to the present inter-national order projects that same order on the ultimate planetary scale: the solution to the moral shortcomings of the earth's Imagined Communities is in imagining the largest community of them all.

The third necessary ingredient that the sea provides for this amplified dramatization is a powerful conceptual repertoire, which helps people make intertextual links between scripture-based moral imperatives and contemporary problems. I will return to the use of this repertoire later. But first, let us turn to the sea.

\section{The Law of the Sea and the Law of the Land}

In the last decade or so, the Mediterranean has once more played this role in European political imaginary. So much so, that in 2013 Pope Francis chose to conduct his first Pastoral Visitation to the island of Lampedusa, where he decried 'the globalization of indifference' to migrants' deaths at sea (Vatican 2013b). Since the creation of the European Union and its unified border regime, Europe's southern shores became the aim of people trying to enter the continent. I've analyzed elsewhere how waves of migration triggered a reinforcement of interception attempts, and how interception in turn facilitated and increased migration flows (Ben-Yehoyada 2011). Here, I focus on how this 
mutual intensification positioned the Mediterranean at the heart of European discussions of the moral and political dimensions of hospitality.

The central-Mediterranean is hardly the most common path people take to migrate illegally to Europe - most of them overstay their tourist visas (Frontex Risk Analysis Unit 2014). Nevertheless, this set of maritime routes has captivated international attention, because it has dramatized the tension between the demands of universal humanity and the exigencies of rule (Manrique Gil et al. 2014, 5). Since 1988, more than twenty thousand people have died along European borders. ${ }^{3}$ Scenes of drowning or abandonment at sea point to the waves of Eurobound migration. Images of capsized boats adrift and bodies washed ashore have become emblems of the fraught relationship between boundless humanity and bounded citizenship (Frenzen 2013); a running thread of recent writing (Agamben 1998; Mbembe 2003; Fassin 2012; Cabot 2014).

In addressing these issues, people framed the moral and the political on different scales. As they demanded, denied, enacted, or judged migration policies under the umbrella of universal hospitality, they sliced the world along the threshold of welcome or trespass in different ways: some of them scaled the political below the moral, others elevated the political above the moral, others still - across it. Here 'scale' and its derived verb - 'to scale' up or down - denote two related moves of framing (Caton 1987) and stagecraft (Shryock 2012). In the first denotation, 'scaling' frames any concrete act of hospitality as that between members of horizontal groups of different sizes: The wider group includes both guest and host, and marks the scale of inclusion that applies to the moral obligation of hospitality. The narrower group marks the host's power over their realm and excludes the guest from being its habitual member. Otherwise, either the host would be unable to extend the welcome, or no welcome would be required. In the second denotation, 'scaling' as stagecraft refers to the construction of the space of hospitality under the specific framing of hospitality. When people 
and institutions 'scale up' or down the frames they project onto encounters, they construct and deploy concrete 'hospitality assemblages... as means to establish the sovereignty' they claim over spaces and groups (Shryock 2012, S24). European migration policies combined both moves.

The dynamics of maritime rescue and interception have positioned the relationship between the moral and the political at the threshold of initial admittance rather than of political incorporation. The struggle between northbound migrants and the European Union's border control agency has increased the overlap between two projects regarding transnational maritime space: the first is the consolidation of the EU's de facto sovereignty over European soil and in the Mediterranean; the second is human rights advocacy for those who try to traverse the sea (Mann $2013,320)$. Sovereignty and human rights may seem like opposed political projects; most of the news items pit them against each other. Nevertheless, the two projects have together promoted the scaling up of European interception efforts under universal hospitality. The call for 'universal hospitality' is framed as a moral obligation and then codified as a legal right, propelling a scaling up in both senses of expansion and consolidation - of the reach of sovereignty into the sea. In this setup, the moral as global in scale, universal in application, and the horizon of action and policy, confronts the political as local, particular, and lacking. At the heart of this disjunction lies a view of universal humanity as a kind of future global order of ubiquitous human rights; an order that is based on panhuman sameness, equality, and brotherhood - and that is yet to be established.

This future moral ideal has justified the EU in expanding its control over maritime space as the leading global force in the spread of the same human rights. To curb clandestine flows, the European Union - in the name of its member states' collective sovereignty - has been centralizing de facto sovereignty over Schengen territory. ${ }^{4}$ The European Union's border agency, Frontex (est. 2004), oversees this centralization, displacing borders 'both inward and outward' (Andersson 2014). 
As Frontex's mission statement justifies it, 'the removal of checks at internal borders makes all Schengen members reliant on the checks made by those member states at the zone's perimeter. Simply put, the Schengen area's border is only as strong as its weakest link' (Frontex 2013).

The same centralization of de facto sovereignty over Schengen territory also extends onto the transnational space of the Mediterranean. This resembles earlier US treatment of Haitian 'boat people.' In this foundational case, the United States' policies regarding the Haitian refugee crisis created de facto sovereignty in extraterritorial waters, which the administration justified under corresponding political-spatial imaginaries (Kahn 2013, 89). In the Mediterranean, the European Union similarly 'extra-territorialised' its enforcement and jurisdiction into the sea (Andrade 2010, 312). The key difference is that in the European case, seaward expansion increased European unification. In developing its control of maritime space, the European Union gradually 'acted much like a single, sovereign administrative state' (Kahn 2013, 289).

At the same time, the justification for this centralization gradually shifted from the 'fight against clandestine immigration' and terrorism during the 2000s (Andrade 2010, 312) to the moral obligation to save human lives in danger at sea (Strik 2014). The project of European unification frames this centralization of de facto sovereignty under a universalist umbrella of human rights and democracy, which it ideologically claims both to epitomize and to spread (Balibar 2004, 189). As the preamble to the EU Strategic Framework on Human Rights and Democracy, puts it (General Secretariat 2012; my emphasis): 'Human rights are universally applicable legal norms. Democracy is a universal aspiration... The EU will continue to throw its full weight behind advocates of liberty, democracy and human rights throughout the world?

Under this mission, the European Union and its Mediterranean member states have pursued various policies over the past decade, such as establishing complex sea and air surveillance 
operations (Feldman 2011) and outsourcing the processing of people intercepted at sea to nonEuropean countries (Baldaccini 2010). Italy for example increased its naval vessels' search and seizure mandate; it formed joint patrols with other EU states; and it promoted bilateral cooperation agreements with non-EU states of departure or transit, most notably in 2008 with Gaddafy's Libya (Pascale 2010). Most importantly perhaps, agreements like that with Libya enabled 'push-back' operations: EU vessels that caught unauthorized migrants before landfall in Italy could take them to North African harbors rather than to Italian shore. During the migration high-seasons of 2008 and 2009, this policy already reduced the number of arrivals in Italy by 92 percent. For a short while before the Arab Spring, this set of policies practically emptied the Mediterranean of its waters.

At the same time, the 'push-back' policies and the framing that justified them encountered critique, which rose together with the intensity of operations at sea. In May 2009, during the events that lead to what has been known as the 'Hirsi case,' a vessel operating under Frontex caught one boat south of Lampedusa and sent it back to Libya. Italy and Frontex justified such 'push-back' operations by breaking the hospitality sequence into two parts: rescue and safe harbor. European vessels intercepted migrants' boats under pretense of rescue - even when no one was in danger under the universal hospitality of the high seas. Yet the policy stopped the hospitality sequence at sea: once the migrants were rescued from drowning, they no longer required any further Italian hospitality. This reasoning did not convince the European Court of Human Rights, which in its 2012 decision on the case prolonged the hospitality sequence from the moment of encounter at sea to the relationship and obligation it triggered. Since the interception at sea brought the persons onboard the intercepted/rescued vessel within the state's jurisdiction, that state's obligation towards human rights law applied from that moment onwards (Papanicolopulu 2013, 422). In a way, the Court criticized Italy and Frontex as 'bad hosts.' 
Together, the expansion of EU sovereignty and human rights 'lawfare' have conditioned the scaling up of European control over the Mediterranean both spatially and temporally. At sea, this meant more patrols, tighter surveillance, and more frequent interceptions. Temporally, the framing of rescue as universal hospitality set the point of delayed reciprocity at the future global reach of universal human rights - a vision that both Human Rights activists and EU officials promote (Mann 2013, 317). As a result, these two projects gradually 'territorialized' the Mediterranean: they turned it into an abstract space of projected universal rights, individuals in need of care, and land-like territorial sovereignty. The Mediterranean turned - quite practically - into Europe's massive offshore guest-chambers, or collective diwan (cf. Shryock 2004, 52).

\section{Holy Mass on the High Seas}

The 2009 seaborne mass staged an alternative scaling of salvage at sea under a different framing of hospitality. When the diocese started planning the visit, the struggle over migration in the Mediterranean was coming to a head. In their attempts to reduce the numbers of arrivals, the EU and Italy have dissuaded fishers and other seafarers from rescuing migrants' vessels in distress. In November 2008, two vessels carrying 650 migrants were drowning offshore Lampedusa. The Italian coastguard station in Lampedusa received their distress call, but the stormy sea that night prevented the coastguard vessels from going out to sea. Two Mazarese trawlers, which were also moored in port because of the weather, left port and rescued most of the migrants (Viviano 2008). Following the event, the Italian Minister of the Interior declared that 'we have to be mean to the clandestini' (Salvia 2009). In response, the Mazara bishop declared (Vecchi 2009):

\footnotetext{
This is not our civilization. These fishers did not think about whether those people said 'thank you' or not, if they came because of plausible motives. They acted as men. I am proud of them, yes. In July I will conduct a Pastoral Visit at sea, off the shore of Lampedusa.
} 
By calling for a national 'mean' attitude, the minister pointed to the role of character in hospitality. The bishop accepted this framing and then reversed it. Rescue at sea, like hospitality, had to do with character (Pitt-Rivers 2011, 437). But that character did not have to reside at the national scale. Instead, the bishop reframed the rescuers from his flock not as Italians, but as men, as Sicilians, and as Christians. This framing stood at the center of the 2009 pastoral visit.

At the heart of the pastoral visit stood the Sacrament of the Eucharist, which the Bishop performed from an altar mounted on the upper deck of an Italian Coastguard ship. ${ }^{5}$ In performances of the Eucharist, the transubstantiation of wine and bread into the blood and flesh of Christ simultaneously signals and collapses the chain of ecclesiastic succession - from Christ's life through the Papal successors of St. Peter to Catholic bishops and their priests (Rubin 1991). The priest collapses this chain by uttering Christ's words at the last supper: 'Take, eat; this is my body... Drink ye all of it; for this is my blood.' As the most frequent sacrament, the Eucharist marks the authority of the bishops who govern its performance. Since the early medieval Church, these persons were bishops, so invested through their ordination, and the settings were their dioceses (Bartlett 1993, 1-4). To paraphrase Weber's definition of the state (Weber 2008, 156), we could say that each Catholic Bishop has the monopoly over the administering of grace within a defined territory. The proof of that authority is the exclusive performance of sacraments within a given territory. By implication, wherever a bishop or his subordinate performs the Eucharist unchallenged, there he could claim to hold exclusive Episcopal powers, or, in other words, spiritual hegemony (Subramanian 2009, 50-52).

The seaborne mass scaled up this link between episcopal powers and space to a panMediterranean scale. It did so through a complex of 'indexical and iconic relations' that it staged between the elements onboard the coastguard and the fishing vessels, and a related complex of 
relations between the ritual setup and the larger 'macrocosmic' orders of the wider Mediterranean and the New Testament, which the specific staging made present in the ritual (Stasch 2011, 161).

The first element of this complex replaced the bounded space of any regular church mass, with the entire Mediterranean. If usual masses take place inside churches that belong to dioceses within the territorial hierarchy of the Catholic Church (Vallier 1971, 482), onboard the Italian Coastguard ship, this stability gave way to a more expansive view of the sacrament's potential. As the bishop explained to me later, since 'God inhabits the universe,' the Eucharist, which is 'the sacrifice that the Church offers to God... cannot be performed only inside a constrictive container [like churches].' On the ship off the shore of Pantelleria, it became a 'cosmic altar... the 'altar's floor [was] the sea' and its 'ceiling was the sky.'

Through the ritual's second element, the Bishop harnessed this divine ubiquity to call the Mazara diocese 'the Church that extends into the Mediterranean [which is] the sea of God' (Mogavero 2011, 49). To justify this, he alluded to Mazara's pivotal role in cross-Mediterranean affairs since the 1960s (Ben-Yehoyada 2014). Through this identification between the city, the diocese, and the Mediterranean, the bishop granted himself episcopal powers in that entire 'sea of God.'

The third element identified the current Mediterranean with the Gospel's Sea of Galilee. To do so, the bishop cited the Christian Democrat Giorgio La Pira, who during the 1950s promoted panmonotheistic peace in the Mediterranean, which he 'rechristened... as "the Great Lake of Tiberias" $(2006,9)$. The seaborne mass ritually enacted that phrase, thus completing the identification between the participants in the ceremony and the figures from evangelical scenes. 
The mass opened with a recitation of the biblical section depicting Jesus walking on the water (Mathew 14:22-33). The homily then connected the biblical excerpt to the attending fishers:

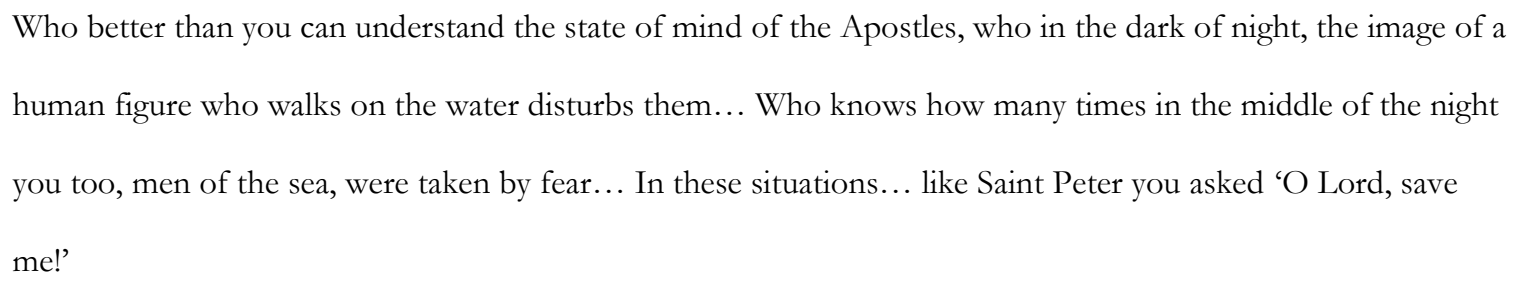

If moments of fear compared the attending fishers to the Apostles, the miraculous response that Jesus provides in the Gospel completed the casting: 'The performance of the mass here with you and for you is intended as a renewed walking of the Lord Jesus on the waters of this sea through the face, the voice, the prayer, and the affection of your bishop.' In his written account of the seaborne mass to the Vatican, the bishop's spelled out and justified the creative identification that had structured the ceremony (Mogavero 2010):

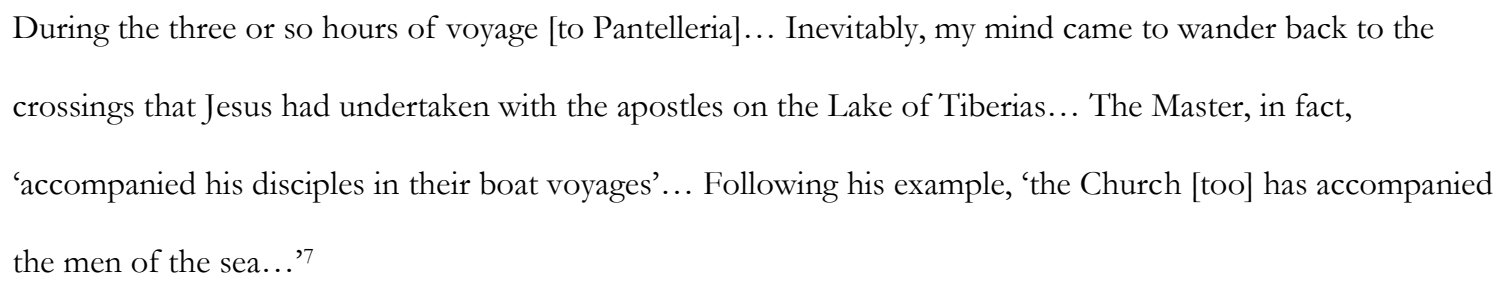

The seaborne mass expanded ritual identification from the Eucharist as its token to all the elements in the ritual setup (Cannell 1995, 384). This complex of resemblances related to each other two scripted relationships: in the past and in the present. The relationship between Jesus and the bishop projected the relationship between Jesus and the Apostles onto the relationship between the bishop and the Mazara fishers. Through this cosmic scheme, the bishop linked the gratuity of maritime rescue to the gratuity of salvation - which upon reception entails obligation: like the Apostles, the fishers of Mazara should become 'fishers of men.' But whereas the Apostles saved souls by spreading the Gospel, the fishers of Mazara would save migrants'souls by rescuing them. 
The bishop framed this mission directly towards the end of the mass, which culminated with the releasing of a wreath of flowers onto the water, followed by a moral accusation. The bishop asked the souls of dead migrants, 'whose hopes for a dignified future were swept away in the bottom of the Mediterranean,' to forgive 'those who have shut their hearts and harbors, turning a deaf ear to pleas for hospitality.' In this setup, if migrants were souls in need of salvation then, by implication, the Italian State and the European Union were Herod and the Pharisees.

Through these biblical allusions, the seaborne mass justified ordinary seafarers' rescuing of migrants in distress. Such a practice, however, is inscribed into various international treaties. ${ }^{8}$ Yet the bishop framed this practice as 'an obligation that is not written in any code or regulation, but is founded on the consciousness that each of us cultivates in our hearts' (Mogavero 2010). If the demand to save lives at sea did not address any legal lacuna, why was it so important? The answer resides in the policies that made such rescue actions legally dangerous (Friese 2010, 332). On the one hand, since the Mazara fleet is so prominent in central Mediterranean, Mazarese fishers have become quite visible as seaborne saviors. ${ }^{9}$ On the other hand, some of Mazara's skippers had gotten into legal trouble after rescuing migrants' boats, because Italian and European legal authorities considered such actions as aiding illegal migration (Marcon 2013). Some Mazarese skippers have told me that they avoid such rescue operations or report sights of migrants' boats to the Italian Coastguard for that exact reason. European migration policies took away from ordinary seafarers the power to decide what constituted rescue and what did not. In a way, the EU and Italy claimed a monopoly as arbiters of correct hospitality.

The seaborne mass challenged this territorialized vision of social relations and obligations. It did so, not from the universal perspective of human rights, but through a regionally specific imaginary of moral obligation, action, and character (Herzfeld 2003). By rendering this written law 
'unwritten,' the bishop turned it into an obligation that all the region's seafarers share, and that some of them fulfill better than others. As he said during the homily:

As Sicilians and Christians, we are firmly convinced that you cannot turn down those who knock on our hearts, even before they knock on our doors: our identity and our culture prohibit such closure.

The two categories - 'Sicilians and Christians' - bracketed the sovereignty of Italy and the EU with the alternative scales of monotheistic religion and subnational culture. This rescaling framed action above Europe, below Italy, and also sideways - through the transnational space of the sea. By saving people in distress, the hospitality of seafarers would make them share in the transitive and hierarchical spreading of salvation, not in the reciprocal, legal, and leveling realm of human rights. The workings of this salvation demanded action across difference - calling Sicilians and Christians to aid those who are not, and who require that aid because they are not - rather than action framed on the basis of the common denominator of human rights, which the saviors and the saved shared. As in other non-state situations (Dresch 2012, 165), this view made 'the capacity to offer refuge' define the fishers' 'moral worth.' 'This alternative framing shaped the wider episcopal project, which culminated with the Pope's visit to Lampedusa.

\section{Jurisdiction Issues}

Until now, I've analyzed the internal logic of the 2009 holy mass. Yet the way in which it framed salvage as salvation triggered jurisdictional dynamics between church and state, as well as among Sicily's bishops. The first instance of such dynamics appeared in the choice of site. The Bishop declared that the reach of the seaborne mass was theologically unbound. Yet the territorial shape of bishoprics confined these liberties. In the meeting at the bishop's office back in 2008, everyone assumed that it would take place off the shore of Lampedusa, and for a good reason. Lampedusa lies closer to the middle of the Tunisian shore and to Libya. In the rising public attention to 
unauthorized migration, Lampedusa, not Pantelleria, took center stage. Yet in the territorial division of dioceses, Lampedusa belongs to the Archdiocese of Agrigento, whereas Pantelleria belongs to Mazara. ${ }^{10}$ The Bishop claimed unbounded spiritual hegemony over the sea. But the ceremony remained within the territorial jurisdiction of his diocese.

The second jurisdictional tension arose during the ceremony itself. While the seaborne mass condemned Italian and European institutions as bad hosts, some Italian politicians attended the mass, and the Italian Coastguard hosted the ceremony. Because of that, the Church's claim to moral hegemony turned into a jurisdictional role-play between Church and State. Two elements in the ceremony reveal this role-play: the mass's choreography, and the sound announcing 'the mystery of the faith.'

When holy masses take place in church, the altar separates the clergy from the audience, including all representatives of terrestrial authorities. During the seaborne mass, all dignitaries naval officers and politicians - stood with the clergy onboard the coastguard ship, while the fishers faced them from their trawler's deck. There was a good reason for this spatial arrangement. The bishop and his clerics perform regular masses in a space they master. Since the Catholic Church no longer possesses its own navy, the Bishop relied on the coastguard's hospitality. As both the bishop and the fleet's administrators told me, it was 'natural' for the Sicilian Coastguard to host the ceremony, and it was equally 'natural' for the bishop to accept the invitation. Yet this conviviality turned the bishop into a guest rather than the master.

I was unaware of how delicate this matter was until I inquired into the second significant choice in the sacrament. In current liturgy, a bell ringing often accompanies the raising of the holy bread and the declaration of the 'mystery of faith.' At sea, the bell was replaced with the naval whistle or 'Bosun's pipe,' which is used during the hoisting of the flag or to honor dignitaries 
onboard. The change of instrument required some modifications, because the sailors could no longer be trusted to know when to blow the whistle. During the mass, one of the priests directed the two sailors entrusted with the whistles, using his index finger to gesture: 'Not yet, not yet... Now!'

When I inquired about the Bosun's Pipe, the bishop's face turned serious and he explained that there was:

no adoption of military symbolism that... how shall I say... would mix sacred and profane, and the most horribly profane! Because military is war, it's violence... But the whistle is the navy's way to give homage. So we gave homage to God in the way that is most appropriate to them... We cast a message of immutable contents in the languages and mental categories of our time.

Glitches in the announcement of the mystery of the faith revealed the 'jurisdictional struggle' the bishop was intent on winning (Palumbo 2004, 5). As a naval idiom of homage, the whistle potentially marked the bishop's 'moral and conceptual subordination' as guest in another master's realm (Herzfeld 1987, 77). By rendering the Navy's ceremonial code as cultural particularities, the bishop tried to explain away its potential implications and reverse the code's moral hierarchy, which cast him in a subordinate position. They might have accommodated his ceremony onboard a State vessel, but he accommodated their mundane ways by translating the immutable message to their mental categories.

\section{The Figure of Jesus from mobilizer to sacrifice}

The seaborne mass revealed the jurisdictional role-play between Church and State. During the Arab Spring, these tensions reemerged on a transnational scale, at sea. The uprisings in Tunisia and Libya reopened the routes of northbound migration, as well as the question of the scale and meaning of universal hospitality. Two events exemplify the tensions that ensued. 
The first event revealed the risks that the Mazara bishop's claim to a spiritual coverage of the sea entailed. From 2008 to 2011, the bishop joined other clerics in addressing the Italian government and the Vatican. In his interventions, he often cited the seaborne mass and Mazarese fishers' rescue operations to promote a transnational episcopal web of communion among Catholic bishops from around the Mediterranean rim (Mogavero 2012). This web of communion was intended as a horizontal alternative to Italian or European mastery of the sea as well as to the future horizon of global human rights.

In January and February of 2011, as Tunisia erupted in revolution, more than 40 thousand Tunisians landed on Italian soil. Italy declared a state of emergency, and tried to convince Tunisia to receive thousands of migrants. When the chances for an agreement were unclear, the Italian interior minister approached his previous adversary, the bishop of Mazara, with an unusual request: to mobilize his transnational episcopal network to help address Italy's border emergency (Custodero 2011). The bishop replied that he was 'willing to intercede' with the bishop of Tunis so that 'the ecclesiastical authorities in Tunisia would provide a space to host those who return' (Sarzanini 2011). Days later, Italy and Tunisia signed the repatriation agreement. The Bishop's entire ritual project had scaled up unconditional hospitality to the level of the church's transnational alternative to the European Unions' mastery over maritime space. By agreeing to help with reversing the flow of migrants, the bishop risked turning his 'web of communion' into a subcontractor of the very Italian and European inhospitality that he had originally challenged. As with the centuries-long history of state-church struggles over the institution of sanctuary for outlaws (Uribe-Uran 2007), the ecclesiastic success in carving out a space of alternative sovereignty and demands on people's actions ended when rulers found a way to contain the church's self-proclaimed autonomy within their own scaled-up spaces of law and power. 
The second event, known as 'the left-to-die boat,' exposed the limits of European naval operations under the umbrella of universal hospitality. In late March 2011, a boat carrying 72 migrants left Tripoli towards Lampedusa. After running out of fuel, the boat drifted for 14 days and emitted several distress calls. Yet although several military ships and airplanes operated in the zone, no one rescued the vessel, which landed back on the Libyan coast carrying only nine survivors (Heller and Pezzani 2013, 2). The case pointed to a wider trend. During the first months of 2011, with so many NATO and Frontex vessels roaming around the central Mediterranean, one Italian official described 'sailing from Libya towards Italy... a bit like doing a slalom between military ships' (quoted in: Strik 2012, 6).

Yet 2011 peaked the death rate at sea, with at least 2,000 deaths. It became clear that even the naval territorialization of the entire Mediterranean would not do. The 'left-to-die boat' case triggered new calls for 'a zero-tolerance approach to death at sea' (Strik 2014, 1). These calls raised the obligation to save lives above the existing legal standards of European sovereignty. In a way, the failure of universal hospitality, which the case exposed, implicated not just any specific European policy, but the collective faulty character of the European Union. As a Human Rights Watch report put it, 'Europe has a responsibility to make sure that preventing deaths at sea is at the heart of a coordinated European-wide approach to boat-migration, not a self-serving afterthought to policies focused on preventing arrivals' (Sunderland 2012,1-2). Other NGOs also foregrounded the question of deaths at sea over their previous focuses on detention policies (Boats4People 2012; WatchTheMed 2012; Migregroup 2014). At the same time, the Sicilian bishops' focus on individual seafarers' obligation to save lives ran its course.

The opportunity to expand the episcopal project came after the election of Pope Francis, in March 2013. This next phase reframed the moral obligation to save lives, and it also changed its 
liturgical grounds: from salvation to sacrifice. In May 2013, the group of Sicilian bishops paid an official visit to the new Pope. During the meeting, the bishop of Mazara and the Archbishop of Agrigento, whose diocese includes Lampedusa, invited the Pope to visit Lampedusa, reiterating a letter that the parish priest of Lampedusa had sent to the Pope inviting him to make a visit 'to the heart of the Mediterranean that is suffering' (Gobbo 2013). The Archbishop of Agrigento also gave the Pope a cross made of wood from boats of migrants 'who had attempted without success the voyage of hope from Africa' (Conferenza Episcopale Siciliana 2013). The gift served as a portable token of the identification between the death of Jesus Christ as sacrifice and that of present-day migrants. And it shifted the liturgical idiom from the transitive and mobilizing working of salvation to that of sacrifice and suffering.

The Pope's visit to Lampedusa in July 2013 continued this shift in liturgical imagery. The Pope boarded an Italian coastguard vessel, released a wreath of flowers onto the waters, and then performed holy mass on land. During the homily, the Pope decried 'the globalization of indifference,' citing the story of Cain and Abel:

\footnotetext{
'Where is your brother? His blood cries out to me,' says the Lord. This is not a question directed to others; it is a question directed to me, to you, to each of us. These brothers and sisters of ours were trying to escape difficult situations to find some serenity and peace... but instead they found death. How often do such people fail to find understanding, fail to find welcome... solidarity. And their cry rises up to God!
}

The Pope's homily reframed the original evangelical scope of the 2009 ceremony to a pan-biblical level in scripture and a panhuman reach in interpretation. The verbal iconography at its core projected brotherhood and the obligation it implies both universally and individually.

At the same time, the sacramental implements in the ceremony continued the evangelical framing of migrant's fates at sea. The chalice holder, the altar, and the podium were made of wood- 
planks of shipwrecked boats. The altar was designed in the shape of a boat, and the podium was made of three rudders of boats' remains. In this spirit, the Archbishop of Agrigento declared during the visit: 'It is Jesus who boards the boat' (Pontificium Consilium pro Familia 2013). Echoing the frequent phrase: 'It's Jesus on the Cross.'

This pronouncement - perhaps the most condensed catholic articulation of migrants' death at sea - identified neither the church with Jesus, nor seaborne saviors with the Apostles. It rather connected the image of Jesus to the migrants themselves: Jesus is the cosmic sacrifice at the center of the New Testament; Jesus preached from a boat at the beginning of his voyage, which ended with his crucifixion; and migrants also board boats and then perish. This new formulation drew a more direct - and perhaps more familiar (Robbins 2013) - connection between victimhood and sacrifice, capsizing and crucifixion. The cartoonist of the Italian communist newspaper Il Manifesto did not miss the opportunity to mock the liturgical identification of migrants' deaths as the Eucharistic wine (Biani 2013).

The Pope's moralizing denouncement of 'the globalization of indifference' resounded three months later, in October 2013, after a boat carrying 518 migrants capsized less than a mile off the coast of Lampedusa in early October 2013, leaving 366 of them dead. The sequence of events during the disaster provided a macabre miniature of the dynamics of unauthorized migration, distress, and interdiction in previous years. When the radio communication did not work, the captain's assistant set fire to a sheet of cloth on deck, in an attempt to attract passing ships. The torched cloth fell into a bucket of gasoline, and the ship went up in flames and started sinking (Viviano 2013). 'Showing flames on the vessel (as from a burning tar barrel, oil barrel, etc.)' is one of the thirteen distress signals that include the Morse code S.O.S., one of the first things that novice 
seafarers learn (United States, Defense Mapping Agency, and Hydrographic/Topographic Center 1990).

Following the disaster, Italian and European officials came to Lampedusa. The Italian Prime Minister, who kneeled in front of several of the coffins, declared that Italy would hold state funerals for the victims. Yet it took another week for the government to organize the ceremony, and the hundreds of corpses were interred in various Sicilian cemeteries. The ceremony eventually took place not in Lampedusa but in Agrigento (on October 21), and included neither the victims' bodies nor any of the 157 survivors, who remained in detention in Lampedusa. The mayor of Agrigento concluded the event as 'a State farce' (Viviano and Ziniti 2013). It was only appropriate that the ceremony to commemorate the deaths at sea, ritually staged the same dynamics of failed hospitality that had provided the cause of commemoration.

The proximity between the pope's visit and the disaster consolidated the centrality of death and rescue as the new frame for addressing migration policies in the Mediterranean. Various actors, including the mayor of Lampedusa Giusi Nicolini - an outspoken critic of European migration policies - connected the Pope's visit and the disaster (Ziniti 2013). This new framing shaped the struggle between Italian and the European institutions over collective moral worth and responsibility - only now of collectives rather than individual fishers. That day, the Pope called the 'umpteenth tragic shipwreck... a disgrace' (Vatican 2013a). The Italian President called the event 'a European tragedy, and the President of the European Commission partially accepted the scale of obligation, if only partially: 'The EU cannot look the other way; we must do more with the Member States' (Ziniti 2013). This struggle still shapes which naval vessels patrol the sea, whom they intercept, and where they take those allegedly rescued. 


\section{Conclusion}

The challenge that the dynamics of maritime migration and interception pose to anthropology is to examine the relationship between the moral and the political not by fixing either of them at the global scale, but through the contested scaling up and down of both, in relation to each other. Scholars like Didier Fassin argue that in our current age the political has merged with the moral and is shaped by the latter's tensions and contradictions (2012). Others, like Miriam Ticktin, analyze the antipolitical potential of moral claims (Ticktin 2011; Feldman 2013; Muehlebach 2013). These two arguments mirror each other's view of 'shared humanity' as the paramount scale of reference: politically, it becomes the ultimate inclusive scope of the 'parity of participation' (Fraser 2010); morally - it becomes the global reach of 'humanitarian reason' (Fassin 2012).

In setting their analytical bar at the global scale, these anthropologists actually align with the universalizing thrust of both Human Rights advocacy and the expansion of the EU's de facto sovereignty into the sea. Advocates, officials, and anthropologists all point to that future global reach of pan-human fraternal parity. Yet in the transnational hospitality arena, which some of them manage and all of them address, this ultimate scale is only one element. In the debate over migration policies through universal hospitality, no one claims that Europeans receive unauthorized migrants say, from West Africa - because Europeans expect the same welcome in case one day they will seek asylum in those migrants' countries. For all the talk of universal hospitality, actual reciprocity doesn't even cross people's minds.

As long as we limit our view of proper political relations to fraternal parity, sameness, and reciprocity, we are bound to reduce the political dimension of action to a local-global continuum of horizontal inclusive scales. This political cosmology calls people to guide their actions towards that dimension of their lives which they share - ultimately, their humanity - and treat with (political) 
suspicion every other dimension. As a result, certain ways of addressing the dilemmas of migration - like 2009 seaborne mass - do not count as political, even though they prescribe more demanding forms of action.

We might wonder whether the Sicilian bishops promote their own kind of armless humanitarianism, a stance which they will never be required (or allowed) to back up. Yet even if this were the case, their interventions still counter the Sicily-Italy-Europe-Globe set of nested horizontal scales by charting relations from the threshold. Like in Andalusian begging customs and Cretan coffeehouses, so in the current Mediterranean, the dynamics of hospitality reside not in the paramount, global scale of inclusion and equality. They rather reside in the tensions between the different scales of inclusion and exclusion, of equality and inequality - some of them concrete, others postulated - which hosts and guests negotiate with each other across the threshold of welcome or trespass.

In the Central Mediterranean, as Europe's threshold moved at sea, so did the scales of responsibility, jurisdiction, and sovereignty. Recently, this scaling up shaped the European Union's plans for military attacks on boats used by migrant smugglers in Libya (Frenzen 2015). Rather than judging such projects according to a prefixed pan-human moral or political bar, we should pay attention to the ways in which people scale the political below the moral (like the EU discourse and the Pope), above it (like EU policies), or across it (like the Mazara Bishop). In order 'to take seriously the achieved spaces of the non-political in which the people we work with have invested themselves' (Candea 2011, 321), we should examine the scope and shape of these spaces in relation to their political counterparts. To do so, we must unmoor our analyses from 'the language of common humanity' and 'the assumption of generalized equality' (Dresch 2012, 163). Venerable ideals they are. Yet they fall short of illuminating the projects of those who proclaim them, let alone the processes 
that their actions trigger. This is where a historical anthropology of region formation can help us animate the grade of scales between the global and the local. Not because regions like the Mediterranean have always been there, but because the dynamics that they stage force us to expand our conceptual framework to include the myriad forms of sociality that transcend the parity-based view of political relations.

The story of migration and interception in the Mediterranean is still unfolding. As we follow it, we should expect that the dilemmas of welcome and trespass will continue to haunt Europeans' political imaginary, with its duo of citizenship and humanity. Yet while the dilemmas of universal hospitality are staged from the Mediterranean, the issues that they conjure up overflow the sea. For migrants to make it beyond the diwan-like space that the Mediterranean has become, other forms of sociality, other political relations, will have to replace hospitality. These forms are more complex than what citizenship and human rights can allow or describe. Short of a global political realm, these political relations will necessarily still involve some combination or another of inclusion and exclusion. If that is so, the moral politics of the diwan may contain priceless clues for the hard work that lies ahead. 


\section{References}

Agamben, Giorgio. 1998. Homo Sacer: Sovereign Power and Bare Life. Translated by Daniel HellerRoazen. Meridian. Stanford, Calif.: Stanford University Press.

Andersson, Ruben. 2014. "Time and the Migrant Other: European Border Controls and the Temporal Economics of Illegality." American Anthropologist 116 (4): 795-809. doi:10.1111/aman.12148.

Andrade, Paula García. 2010. "Extraterritorial Strategies To Tackle Irregular Immigration By Sea: A Spanish Perspective." In Extraterritorial Immigration Control, edited by B. Ryan and V. Mitsilegas, 305-40. Martinus Nijhoff Publishers. http://booksandjournals.brillonline.com.ezpprod1.hul.harvard.edu/content/books/10.1163/ej.9789004172333.i-441.72.

Baldaccini, Anneliese. 2010. "Extraterritorial Border Controls In The Eu: The Role Of Frontex In Operations At Sea." In Extraterritorial Immigration Control, edited by B. Ryan and V. Mitsilegas, 225-51. Martinus Nijhoff Publishers. http://booksandjournals.brillonline.com.ezpprod1.hul.harvard.edu/content/books/10.1163/ej.9789004172333.i-441.53.

Balibar, Etienne 1942-. 2004. We, the People of Europe?: Reflections on Transnational Citizenship. English. Translation/transnation. Princeton, N.J.: Princeton University Press.

Bartlett, Robert. 1993. The Making of Europe: Conquest, Colonization, and Cultural Change, 950-1350. Princeton, N.J.: Princeton University Press.

Benhabib, Seyla. 2004. The Rights of Others: Aliens, Residents and Citizens. The John Robert Seeley Lectures. Cambridge: Cambridge University Press.

Benton, Lauren A. 2010. A Search for Sovereignty: Law and Geography in European Empires, 1400-1900. Cambridge; Cambridge University Press.

Ben-Yehoyada, Naor. 2011. "The Clandestine Central Mediterranean Passage." Middle East Report 266: $18-23$.

—. 2014. "Transnational Political Cosmology: A Central Mediterranean Example." Comparative Studies in Society and History 56 (04): 870-901. doi:10.1017/S0010417514000437.

Biani, Mauro. 2013. "Transustanziazione: Lunedì Il Papa a Lampedusa; E Un Calice Intagliato Dal Legno Dei Barconi Dei Migranti." Originally Published in Il Manifesto. July 7. http://maurobiani.it/2013/07/07/transustanziazione/.

Boats4People. 2012. "Boats4People's First Campaign Is a Success, the Maritime Borders of the EU Remain Are as Deadly as Ever." Migregroup. July 20. http://www.migreurop.org/article2197.html?lang=en.

Cabot, Heath. 2014. On the Doorstep of Europe: Asylum and Citizenship in Greece. First edition. Ethnography of Political Violence. Philadelphia, PA: University of Pennsylvania Press.

Candea, Matei. 2011. "'Our Division of the Universe': Making a Space for the Non-Political in the Anthropology of Politics." Current Anthropology 52 (3): 309-34.

— 2012. "Derrida En Corse? Hospitality as Scale-Free Abstraction." Journal of the Royal Anthropological Institute 18 (June): S34-48. doi:10.1111/j.1467-9655.2012.01759.x.

Candea, Matei, and Giovanni Da Col. 2012. "The Return to Hospitality." Journal of the Royal Antbropological Institute 18 (June): S1-19. doi:10.1111/j.1467-9655.2012.01757.x.

Cannell, Fenella. 1995. "The Imitation of Christ in Bicol, Philippines." The Journal of the Royal Anthropological Institute 1 (2): 377-94. doi:10.2307/3034694.

Caton, Steven C. 1987. "Power, Persuasion, and Language: A Critique of the Segmentary Model in the Middle East.” International Journal of Middle East Studies 19 (1): 77-101. 
Conferenza Episcopale Siciliana. 2013. "Conferenza Episcopale Siciliana - I VESCOVI DI SICILIA IN VATICANO.” May 20.

http://www.chiesedisicilia.org/chiese_di_sicilia/ufficio_stampa/00002096_I_VESCOVI_D I_SICILIA_IN_VATICANO.html.

Custodero, Alberto. 2011. "Immigrati, Lampedusa allo stremo quattromila sbarchi in quattro giorni." La Repubblica, February 13, sec. Cronaca.

Del Grande, Gabriele. 2006. "Fortress Europe: La Strage.” Blog. Fortress Europe, Osservatorio Sulle Vittime Della Frontiera. http:// fortresseurope.blogspot.it/p/la-strage.html.

Dresch, Paul. 2012. "Aspects of Non-State Law: Early Yemen and Perpetual Peace." In Legalism, edited by Paul Dresch and Hannah Skoda, 145-72. Oxford University Press. http://www.oxfordscholarship.com/view/10.1093/acprof:oso/9780199664269.001.0001/a cprof-9780199664269-chapter-6.

Fassin, Didier. 2012. Humanitarian Reason: A Moral History of the Present. Berkeley: University of California Press.

Feldman, Gregory. 2011. The Migration Apparatus: Security, Labor, and Policymaking in the European Union. Stanford University Press. . 2013. "The Specific Intellectual's Pivotal Position: Action, Compassion and Thinking in Administrative Society, an Arendtian View.” Social Anthropology 21 (2): 135-54. doi:10.1111/1469-8676.12022.

Fraser, Nancy. 2010. "Injustice at Intersecting Scales: On 'Social Exclusion' and the 'Global Poor."' European Journal of Social Theory 13 (3): 363-71. doi:10.1177/1368431010371758.

Frenzen, Niels. 2015. "Frontex Director: EU Military Operation Near Libya May Shift Migration Routes to Eastern Mediterranean.” Blog. Migrants at Sea. June 5. http://migrantsatsea.org/2015/06/05/ frontex-director-eu-military-operation-near-libyamay-shift-migration-routes-to-eastern-mediterranean/.

- 2013. "Chappatte on the Latest Disaster at Lampedusa." MIGRANTS AT SEA. Accessed November 11. http://migrantsatsea.wordpress.com/2013/10/06/chappatte-on-the-latestdisaster-at-lampedusa-2/.

Friese, Heidrun. 2010. "The Limits of Hospitality: Political Philosophy, Undocumented Migration and the Local Arena." European Journal of Social Theory 13 (3): 323-41. doi:10.1177/1368431010371755.

Frontex. 2013. "Frontex | Roles and Responsibilities.” Accessed November 5. http://www.frontex.europa.eu/operations/roles-and-responsibilities.

Frontex Risk Analysis Unit. 2014. “Annual Risk Analysis.” 5119 / 2014. Warsaw: Frontex, European Agency for the Management of Operational Cooperation at the External Borders of the Member States of the European Union.

http://frontex.europa.eu/assets/Publications/Risk_Analysis/Annual_Risk_Analysis_2014.p df.

General Secretariat. 2012. EU Strategic Framework and Action Plan on Human Rights and Democracy. Luxembourg.

Gobbo, Romina. 2013. "Don Stefano Nastasi: 'Se Il Papa Venisse a Lampedusa...”' Famiglia Cristiana, March 23. http://www.famigliacristiana.it/articolo/parroco-di-lampedusa-e-papa.aspx.

Grotius, Hugo. 1916. The Freedom of the Seas, Or, The Right Which Belongs to the Dutch to Take Part in the East Indian Trade a Dissertation [1609]. Edited by James Brown Scott. Translated by Ralph Van Deman Magoffin. New York: Oxford University Press.

Heller, Charles, and Lorenzo Pezzani. 2013. "Addendum to the "'Report on the Left-To-Die Boat."'” Forensic Oceanography. http://www.forensic-architecture.org/case/left-die-boat/. 
Herzfeld, Michael. 1987. “'As in Your Own House': Hospitality, Ethnography, and the Stereotype of Mediterranean Society." In Honor and Shame and the Unity of the Mediterranean, edited by David D Gilmore, 75-89. A Special Publication of the American Anthropological Association ; No. 22. Washington, D.C.: American Anthropological Association.

. 2003. "Localism and the Logic of Nationalistic Folklore: Cretan Reflections." Comparative Studies in Society and History 45 (2): 281-310. doi:10.2307/3879317.

- 2005. "Practical Mediterraneanisms." In Rethinking the Mediterranean. William Harris, Ed., edited by William V. Harris, 45-63. Oxford: Oxford University Press.

International Maritime Organization. 1989. International Convention for the Safety of Life at Sea (SOLAS). London: IMO.

. 2002. COLREG: Convention on the International Regulations for Preventing Collisions at Sea, 1972. Consolidated 2002, 3rd. London: International Maritime Organization.

Kahn, Jeffrey Sterling. 2013. "Islands of Sovereignty: Haitian Migration and the Borders of Empire." Ph.D., United States -- Illinois: The University of Chicago. http://search.proquest.com.ezpprod1.hul.harvard.edu/dissertations/docview/1346011702/abstract/D913DD07DCA044C CPQ/1?accountid=11311.

Kant, Immanuel. 2006. Toward Perpetual Peace and Other Writings on Politics, Peace, and History. Edited by Pauline Kleingeld. Rethinking the Western Tradition. New Haven: Yale University Press.

La Pira, Giorgio. 2006. Il Grande Lago Di Tiberiade: Lettere Di Giorgio La Pira per La Pace Nel Mediterraneo: 1954-1977. Edited by Marco Pietro Giovannoni. I Libri Della Badia 7. Firenze: Polistampa.

Lévi-Strauss, C. 1969. The Elementary Structures of Kinship. Vol. Rev. Boston,: Beacon Press.

Mann, Itamar. 2013. "Dialectic of Transnationalism: Unauthorized Migration and Human Rights, 1993-2013.” Harvard International Law Journal 54 (2): 315-91.

Manrique Gil, Manuel, Judit Barna, Pekka Hakala, Benjamin Rey, and Eulalia Claros. 2014. "Mediterranean Flows into Europe: Migration and the EU's Foreign Policy." DG EXPO/B/PolDep/Note/2014_5. Brussels: Directorate-General for External Policies of the Europan Union, Policy Department.

Marcon, Giulio. 2013. “Mare Nostrum, Un'esibizione Militar-Umanitaria.” Il Manifesto, October 15. http://ilmanifesto.it/mare-nostrum-unesibizione-militar-umanitaria/.

Mbembe, Achille. 2003. “Necropolitics.” Public Culture 15 (1): 11-40. doi:10.1215/08992363-15-1-11.

Migregroup. 2014. "Qui Sommes-Nous ?" Migregroup: Observatoire de Frontières. Accessed September 6. http://www.migreurop.org/rubrique378.html?lang=fr.

Mogavero, Domenico. 2010. "Visita pastorale nel Mare Mediterraneo Segno e memoria; Letter to the Comitato internazionale dell'apostolato del mare per la pesca," February 10. 2011. La Chiesa che non tace. Bur. . 2012. "IMMIGRATI: CHIESA E STATO INTERVENGONO (D.MOGAVERO) ;" Fondazione Migrantes - Servizio Migranti 1/12. http://www.chiesacattolica.it/documenti/2012/03/00015628_immigrati_chiesa_e_stato_int ervengono_d_m.html.

Muehlebach, Andrea. 2013. "The Catholicization of Neoliberalism: On Love and Welfare in Lombardy, Italy." American Anthropologist 115 (3): 452-65. doi:10.1111/aman.12028.

Palumbo, Berardino. 2004. "The War of the Saints': Religion, Politics, and the Poetics of Time in a Sicilian Town." Comparative Studies in Society and History 46 (1): 4-34.

Papanicolopulu, Irini. 2013. "International Decisions; Hirsi Jamaa v. Italy. Application No. 27765/09." American Journal of International Law 107: 417-23. 
Pascale, Alessia Di. 2010. "Migration Control At Sea: The Italian Case.” In Extraterritorial Immigration Control, edited by B. Ryan and V. Mitsilegas, 274-304. Martinus Nijhoff Publishers.

http://booksandjournals.brillonline.com.ezpprod1.hul.harvard.edu/content/books/10.1163/ej.9789004172333.i-441.65.

Pitt-Rivers, Julian Alfred. 1977. The Fate of Shechem: Or, The Politics of Sex: Essays in the Anthropology of the Mediterranean. Cambridge Studies in Social Anthropology ; No. 19. Cambridge [Eng.]: Cambridge University Press.

- 2011. "The Place of Grace in Anthropology." HAU: Journal of Ethnographic Theory 1 (1): 423-50.

Pontificium Consilium pro Familia. 2013. "È Gesù Che Sale in Barca." Pontifical Council for the Family. July 8.

http://www.familiam.org/famiglia_ita/chiesa/00004934_E_Gesu_che_sale_in_barca.html.

Pope John Paul II. 1997. “Apostolic Letter 'Motu Proprio' Stella Maris on the Maritime Apostolate,” January 31.

http://www.vatican.va/holy_father/john_paul_ii/motu_proprio/documents/hf_jpii_motu-proprio_17031999_stella-maris_en.html.

Robbins, Joel. 2013. "Beyond the Suffering Subject: Toward an Anthropology of the Good." Journal of the Royal Anthropological Institute 19 (3): 447-62. doi:10.1111/1467-9655.12044.

Rubin, Miri. 1991. Corpus Christi: The Eucharist in Late Medieval Culture. Cambridge [England]; New York: Cambridge University Press.

Sahlins, Marshall D. 1981. Historical Metaphors and Mythical Realities: Structure in the Early History of the Sandwich Islands Kingdom. ASAO Special Publications ; No. 1. Ann Arbor: University of Michigan Press.

- 2013. What Kinship Is-- and Is Not. Chicago: The University of Chicago Press, 2013, C2013.

Salvia, Lorenzo. 2009. "Maroni: Cattivi Con I Clandestini." Corriere Della Sera, February 3.

Sarzanini, Fiorenza. 2011. "Le Richieste: Rimpatri E Coste «bloccate»." Corriere Della Sera, April 4.

SergioOlivaMarsala. 2009. Visita Pastorale in Mare 2009 Del Vescovo Di Mazara Mogavero Santa Messa Parte 1. http:/ / www.youtube.com/watch?v=IHBfxDgtBzc\&feature=youtube_gdata_player.

Shryock, Andrew. 2004. "The New Jordanian Hospitality: House, Host, and Guest in the Culture of Public Display." Comparative Studies in Society and History 46 (01): 35-62. doi:10.1017/S0010417504000039.

. 2008. "Thinking about Hospitality, with Derrida, Kant, and the Balga Bedouin." Anthropos 103 (2): 405-21.

. 2009. "Hospitality Lessons: Learning the Shared Language of Derrida and the Balga

Bedouin." Paragraph : The Journal of the Modern Critical Theory Group. 32 (1): 32.

—. 2012. "Breaking Hospitality Apart: Bad Hosts, Bad Guests, and the Problem of Sovereignty." Journal of the Royal Anthropological Institute 18 (June): S20-33. doi:10.1111/j.14679655.2012.01758.x.

Stasch, Rupert. 2011. "Ritual and Oratory Revisited: The Semiotics of Effective Action." Annual Review of Anthropology 40 (1): 159-74. doi:10.1146/annurev-anthro-081309-145623.

Steinberg, Philip E. 2001. The Social Construction of the Ocean. Vol. 78. Cambridge Studies in International Relations ; 78. Cambridge ;New York: Cambridge University Press.

Strik, Tineke. 2012. "Lives Lost in the Mediterranean Sea: Who Is Responsible?" 12895. Parliamentary Assembly, Council of Europe. http://assembly.coe.int/ASP/XRef/X2HDW-XSL.asp?fileid $=18095 \& l a n g=$ en.

. 2014. “The 'left-to-Die Boat': Actions and Reactions.” 13532. Parliamentary Assembly, Council of Europe. 
Subramanian, Ajantha. 2009. Shorelines: Space and Rights in South India. Stanford, Calif.: Stanford University Press.

Sunderland, Judith. 2012. "Hidden Emergency - Migrant Deaths in the Mediterranean." Human Rights Watch. http://www.hrw.org/node/109445.

Ticktin, Miriam Iris. 2011. Casualties of Care: Immigration and the Politics of Humanitarianism in France. Berkeley: University of California Press.

Tillion, Germaine. 1983. The Republic of Cousins : Women's Oppression in Mediterranean Society. London: Al Saqi Books.

UNHCR. 2007. "I Edizione Del Premio 'Per Mare Cerimonia Di Premiazione A Mazara Del Vallo UNHCR.” ottobre. http://www.unhcr.it/news/dir/26/view/235/i-edizione-del-premio-aper-mare-cerimonia-di-premiazione-a-mazara-del-vallo-23500.html.

—. 2008. "II Edizione Del Premio 'Per Mare Cerimonia Di Premiazione A Mazara Del Vallo UNHCR.” ottobre. http://www.unhcr.it/news/dir/26/view/93/ii-edizione-del-premio-aper-marea-cerimonia-di-premiazione-a-palermo-9300.html.

United States, Defense Mapping Agency, and Hydrographic/Topographic Center. 1990. International Code of Signals: Sound and Radio Communications. [Washington, D.C.]: Defense Mapping Agency. Hydrographic/Topographic Center.

Uribe-Uran, Victor M. 2007. "Iglesia Me Llamo': Church Asylum and the Law in Spain and Colonial Spanish America." Comparative Studies in Society and History 49 (2): 446-72.

Vallier, Ivan. 1971. "The Roman Catholic Church: A Transnational Actor." International Organization 25 (3): 479-502. doi:10.2307/2706052.

Vatican. 2013a. "Ai Partecipanti All'incontro Promosso Dal Pontificio Consiglio Della Giustizia E Della Pace, Nel 50 Anniversario Della 'Pacem in Terris."' La Santa Sede. ottobre. http://w2.vatican.va/content/francesco/it/speeches/2013/october/documents/papafrancesco_20131003_50-pacem-in-terris.html.

—. 2013b. "Visit of Holy Father Francis to Lampedusa." La Santa Sede. July 8. http://www.vatican.va/holy_father/francesco/travels/2013/papa-francesco-lampedusa20130708_en.html.

Vecchi, Gian Guido. 2009. “"Non è La Nostra Civiltà»»." Corriere Della Sera, February 3.

Viviano, Francesco. 2008. "Lampedusa, Pescherecci Nella Burrasca per Salvare 650 Immigrati in Difficoltà." La Repubblica, November 28, sec. Cronaca. http://www.repubblica.it/2008/11/sezioni/cronaca/clandestini/clandestini/clandestini.htm 1 .

. 2013. "Lampedusa, Arrestato Il ‘Capitano': 'Fa Parte Dei Trafficanti Di Esseri Umani.” La Repubblica.

http://www.repubblica.it/cronaca/2013/10/08/news/lampedusa_in_carcere_l_uomo_che_ guidava_il_barcone_della_strage-68143898/?ref=search.

Viviano, Francesco, and Alessandra Ziniti. 2013. "Migranti, Contestato Alfano Assassino, Cancella La Bossi-Fini." La Repubblica.

http:/ / ricerca.repubblica.it/repubblica/archivio/repubblica/2013/10/22/migranticontestato-alfano-assassino-cancella-la-bossi-fini.html?ref $=$ search.

WatchTheMed. 2012. “About WTM | Watch the Med.” Watch THE MED. http://watchthemed.net/index.php/page/index/3.

Weber, Max. 2008. Max Weber's Complete Writings on Academic and Political Vocations. Edited by John Dreijmanis. Translated by Gordon C. Wells. Algora Publishing. 
Ziniti, Alessandra. 2013. "Lampedusa, Contestati Letta E Barroso.” La Repubblica, October 10. http:/ / ricerca.repubblica.it/repubblica/archivio/repubblica/2013/10/10/lampedusacontestati-letta-barroso.html?ref=search. 
${ }^{1}$ For their comments and suggestions, I am grateful to Anna and David Abulafia, Kerry Chance, Alireza Doostdar, Nicholas Harkness, Daniel Hershenzon, Michael Gilsenan, Jeffery Kahn, Julie Kleinman, Alaina Lemon, Darryl Li, Jonathan Mair, Itamar Mann, Jessica Marglin, Maria Minicuci, Andrea Muehlebach, Anastasia Piliavsky, Theodoros Rakopoulos, Joel Robbins, Jane and Peter Schneider, Andrew Shryock, Ben Siegel, Rupert Stasch, Ajantha Subramanian, Corey Tazzara, Alice Wilson, and Emrah Yildiz, the participants of seminars at Maynooth, Cambridge, Harvard, and UCL, as well as Matei Candea, Justin Dyer, and the anonymous reviewers of JRAI.

${ }^{2}$ Other political cosmologies cast those who arrive from the sea, like 'stranger kings' in general, in a more complementary, albeit usurping role; under the principle that alterity and externality are conditions of reproduction (Sahlins 1981; Candea and Da Col 2012).

${ }^{3}$ The information comes from Gabriele Del Grande's website, which since 2006 has served as a unique 'observatory on the frontier's victims' (Del Grande 2006).

${ }^{4}$ Schengen territory is the area comprising the 26 European countries that have unified their visa policies and eliminated passport control for their citizens travelling across the area's 'internal' borders.

${ }^{5}$ The entire Mass can be viewed in four parts on YouTube (SergioOlivaMarsala 2009).

${ }^{6}$ Interview, 8 May 2013.

${ }^{7}$ The embedded quotes comes from Pope John Paul II's Apostolic Letter, 'Stella Maris on the Maritime Apostolate' (1997).

${ }^{8}$ Mainly those concerning the Safety of Life at Sea, SOLAS; and the Regulations for Preventing Collisions at Sea, COLREG (International Maritime Organization 1989; 2002).

${ }^{9}$ For example, both in 2007 and 2008, the UN High Commissioner for Refugees awarded fishers from Mazara the Per Mare award 'for those who save human lives' (UNHCR 2007; 2008). 
${ }^{10}$ For the territorial division of dioceses in Sicily, see:

https://commons.wikimedia.org/wiki/File:Regione ecclesiastica Sicilia.png; accessed 17 June, 2015. 